Original Research Paper

\title{
Penerapan Teknologi Budidaya Ramah Lingkungan Pada Nelayan Kecil di Desa Ketapang Raya Lombok Timur
}

\author{
Abdul Syukur ${ }^{1 *}$, Khairuddin ${ }^{1}$, M. Yamin ${ }^{1}$ \\ ${ }^{1}$ Program Studi Pendidikan Biologi Fakultas Keguruan dan Ilmu Pendidikan, Universitas Mataram
}

*Corresponding Author:

Syukur, Program Studi

Pendidikan Biologi Fakultas

Keguruan dan Ilmu Pendidikan,

Universitas Mataram, Indonesia;

Email:

syukurbiologi@unram.ac.id.com

\begin{abstract}
Abstrak: Wilayah pesisir memiliki potensi ekonmi yang dapat dikembangkan sebagai sumber pendapatan baru nelayan kecil. Budidaya ramah lingkungan dapat menjadi solusi dalam mengurangi kemiskinan nelayan. Tujuan program pengabdian pada masyarakat ini adalah: (1) pengembangan budidaya berbasis potensi bibit lokal sebagai sumber matapencaharian berkelanjutan nelayan skala kecil, (2) meningkatkan peran nelayan skala kecil untuk meningkatkan produksi perikanan laut melalui budidaya, (3) penguatan kapasitas kelembagaan kelompok nelayan untuk mengembangkan budidaya di lokasi studi, (4) mengintegrasikan nilai budidaya dalam usaha konservasi lamun skala lokal, (5) budidaya menjadi sektor unggulan dalam menjaga stabilitas stok pangan secara berkelanjutan dan (6) budidaya dan konservasi lamun skala lokal menjadi instrumen pengelolaan perikanan berkelanjutan. Pendekatan yang digunakan adalah pendekatan kooperatif melalui sistem pembelajaran orang dewasa (andragogi) dengan metode contoh (damplots), diskusi kelompok, Fokus Group Discussion (FGD) dan wawancara. Hasil dari program pengabdian pada masyarakat ini adalah nelayan kecil dapat menerapkan teknologi budidaya ramah lingkungan. Indikator dari teknologi ramah lingkungan adalah budidaya dilakukan dengan menggunakan bagang apung sederhana untuk memperoleh pakan udang yang sebelumnya mereka banyak mengambil pakan dari biota laut pada lokasi padang lamun. Hasil lain yang cukup postif adalah nelayan skala kecil di Desa Ketapang Raya memiliki matapencaharian baru yang dapat meningkatkan pendapatan mereka. Kesimpulan dari program pengabdian pada masyarakat ini adalah nelayan kecil dapat menerapkan teknologi budidaya ramah lingkungan dan memiliki nilai positif sebagai sumber matapencaharian yang berkelanjutan serta dapat menciptakan lapangan kerja baru untuk masyarakat dan keluarga nelayan.
\end{abstract}

Kata kunci: Budidaya ramah lingkungan dan dan Matapencaharian nelayan kecil

\section{Pendahuluan}

Desa Ketapang Raya memiliki potensi sumberdaya alam yang cukup potensial sebagai sumber ekonomi masyarakat. Sumberdaya lingkungan tersebut berupa peraian pantai dan perairan muara (estuaria) di bagain utara dan selatan (Profil Desa Ketapang Raya, 2014). Potensi lingkungan laut terutama perairan pantai yang didukung oleh potensi bibit beberapa ikan ekonomis penting seperti ikan baronag belum dimanfaatakan secara optimal menjadi sumber ekonomi produktif (Syukur et al., 2016). Berkaitan dengan berkembanganya usaha nelayan kecil untuk mencari suplemen matapencaharaian koperasi nelayan yaitu koperasi serba usaha masyarakat pesisir karyabersama pada tahun 2014 membentuk dua kelompok nelayan pembudidaya yaitu kelompok budidaya bintang laut dan kelompok budidaya muara hijau. Kedua kelompok nelayan pembudidaya memiliki motivasi yang cukup besar untuk mengembangkan budidaya sebagai suplemen matapencahrian sebagai nelayan tangkap. Dalam hal ini budidaya ramah lingkungan di Desa Ketapang Raya dapat menjadi instrumen pengembangan ekonomi nelayan dan secara teoritas budidaya ramah lingkungan memiliki makna sebagai komplementri 
dari usaha perikanan tangkap dan akan berkembang menjadi sumber matapencaharian utama yang berkelanjutan (Perez et al., 2012).

Budidaya laut yaitu budidaya lobster yang dikembangkan oleh nelayan skala kecil di lokasi pengabdian pada masyarakat telah berkontribusi sebagai sumber matapencaharian baru. Namun demikina sarana kramba jaring apung (KJA) belum dilengkapi dengan bagang apung untuk memperoleh pakan. Oleh karena itu pengembangan teknologi budidaya ramah lingkungan dapat menjadi solusi untuk mengatasi masalah ekonomi nelayan skala kecil dan mencegah keberlanjutan eksploitasi biota laut di lokasi pengabdian pada masyarakat. Dalam hal ini Tim pengabdian pada masyarakat dari Universitas Mataram menilai bahawa budidaya yang telah dilakukan oleh nelayan skala membutuhkan teknologi agar budidaya dapat menjadi solusi ekonomi dan instrumen untuk mengatasi masalah kerusakan lingkungan akibat over-eksploitasi.

Kelompok budidaya nelayan bintang laut dan kelompok budidaya nelayan muara hijau dapat dikatgorikan sebagai kelompok usaha mikro atau kelompok usaha kecil yang hanya mampu melibatkan anggota keluarga. Profil dari kelompok budidaya bintang laut adalah: (1) budidaya pada lingkungan perairan pantai, (2) jenis budidaya ikan baroang dan lobster, (3) matapencahrian utama sebagai nelayan, (4) alat untuk budidaya keramba jaring apung (KJA) dan (5) usaha budidaya secara berkelompok dan hanya melibatkan anggota keluarga. Selanjutnya profil kelompok nelayan muara hijau adalah: (1) budidaya pada lingkungan muara, (2) jenis budidaya ikan dan kepiting bakau, (3) matapencaharian utama nelayan, (4) alat untuk budidaya ikan KJA dan untuk kepiting bakau kurungan bambu dan (5) usaha budidaya hanya melibatkan anggota keluarga.

Aspek produksi dari kedua kelompok nelayan masih belum optimal. Hal ini disebabkan karena masalah pakan yang sulit diatasi oleh kedua kelompok pembudidaya. Manajemen usaha dari kedua kelompok mitra yang berkaitan dengan pengadaan input produksi dan proses selama budidaya dikelola secara langsung oleh tiap nelayan pembudidaya. Namun hal-hal yang berkaitan dengan keamanan dalam budidaya dikelola secara kelompok. Masalah mendasar yang dihadapi oleh kedua mitra untuk mengembangkan budidaya adalah: (1) orientasi yang masih mengharapkan bantuan langsung untuk mengembangkan usaha baru seperti usaha budidaya, (2) kebutuhan pakan untuk budidaya yang masih sulit diatasi oleh para anggota kelompok, (3) belum ada teknologi yang dapat mengatasi masalah kebutuhan pakan budidaya nelayan kecil dan (4) belum ada penguatan kapasitas kelompok secara sosial dan ekonomi untuk menjadi kelompok pembudidaya yang madiri dan berkelanjutan.

Permasalahan lain yang dihadapi oleh kelompok nelayan untuk mendukung usaha budidaya adalah penurunan produksi ikan target seperti: (1) ikan lemuru sebesar $82,15 \%$, (2) ikan cucut sebesar 70,11\% dan (3) ikan layang sebasar 11 (BPS Lombok Timur, 2014) dan jenis ikan lemuru, tembang, dan cumi-cumi yang sudah melampaui jumlah tangkapan yang diperbolehkan di perairan laut Tanjung Luar dan sekitarnya dan bahkan cumicumi sudah melampaui potensi lestarinya (Karnan et al., 2012). Kondisi ini menyebabkan semakin sulitnya bagi anggota kelompok mitra untuk mengembangkan budidaya pada skala yang lebih banyak, akibat dari ketidakmampuan untuk mambuat sarana budidaya.

Parameter-parameter seperti pendapatan nelayan skala kecil dan jumlah populasi nelayan adalah faktor utama yang menjadi fokus untuk mengatasi masalah kemiskinan nelayan skala kecil di Desa Ketapang Raya. Oleh karena itu dibutuhkan alternatif matapencaharian baru yang bersumber dari lingkungan sekitar di Desa Ketapang Raya. Masyarakat dan nelayan skala kecil di Desa Ketapang Raya sebenarnya memiliki potensi yang bersifat responsif dalam mencari alternatif matapencaharian baru seperti sebagai penangkapan bibit lobster secara berkelompok dengan menggunakan sistem Keramba Apung (KA). Selain itu, di wilayah perairan pesisir pada lokasi pengabdian memiiki potens untuk mendukung budidaya dari beberapa parameter yaitu dari ketersediaan bibit ikan ekonomis penting dan pakan secara alami serta ada regulasi secara informal dari kelompok pembudidaya. Dalam hal ini budidaya ramah lingkungan di wilayah pesisir Tanjung Luar Lombok Timur dapat menjadi instrumen dalam meningkatkan status ekonomi nelayan skala kecil dan konservasi lingkungan laut. Faktor lain yang mendukung dalam pengembangan budidaya dengan nelayan kecil sebagai sasaran di lokasi pengabdian pada masyarakat adalah mereka memiliki pengetahuan yang cukup baik tentang perubahan ekosistem laut secara spatial dan temporal, status 
biota biota laut yang bernilai ekonomi dan pentingnya keutuhan ekosistem laut untuk keberlanjutan biota laut dan ekonomi masyarakat local (Syukur, 2013).

Nelayan skala kecil pada lokasi pengabdian pada masyarakat dalam kurun waktu dua tahun telah mulai melakukan budidaya laut yaitu budidaya lobster. Budidaya lobster yang dilakukan oleh nelayan skala kecil memiliki implikasi dari aspek lingkungan yang kurang baik. Hal ini disebabkan karena para pembudidaya melakukan eksploitasi terhadap beberapa biota laut dari kelompok echinodermata sebagai sumber pakan budidaya. Oleh karena itu dibutuhkan teknologi untuk memperoleh pakan yang bersumber dari hasil tangkapan ikan kecil dari sekitar (Syukur, et al., 2017). Salah satu model yang dapat dikembangkan oleh nelayan skala kecil untuk pengembangan budidaya laut di lokasi studi adalah teknologi sederhana pada sistem KJA yang dapat berfugsi sebagai bagang apung untuk mendapatkan jenis ikan-ikan kecil yang dapat menjadi sumber pakan budidaya dan memiliki nilai ekonomi rendah. Dalam hal ini tantangan yang dihadapi oleh para pembudidaya adalah bertambahnya sarana yang diperlukan untuk melakukan budidaya laut. Namun demikian ancaman ekosistem seperti ekosistem padang lamun sebagai kompenen lingkungan utama untuk keberlanjutan budidaya adalah faktor penting yang harus menjadi pertimbangan Dalam hal ini, status konservasi lamun di luar areal konservasi dapat menjadi pilihan kebijakan untuk mendukung usaha budidaya di lokasi pengabdian pada masyarakat (Syukur, 2015).

Program budidaya ramah lingkungan untuk pemberdayaan kelompok nelayan bintang laut dan kelompok nelayan muara hijau di Desa Ketapang adalah solusi objektif dan rasional untuk mengatasi masalah kemiskinan kelompok nelayan. Objekvitas dan rasionalitas dari program budidaya ramah lingkungan ini didasarkan atas beberapa hal yaitu: (1) biaya produksi murah karena bibit diperoleh lingkungan sekitar seperti bibit ikan yang bernilai ekonomi (baronag, kakap, bandeng dan lain-lain) dan lobster , (2) resiko kematian bibit sangat kecil karena lingkungan secara alami tidak berbeda dengan lingkungan tempat pembesaran yaitu keramba jaring apung (KJA) dan (3) keamanan lebih mudah karena dilakukan secara berkelompok dan tidak jauh dari tempat tinggal
Penerapan teknologi budidaya ramah lingkungan sebagai program pengabdian pada masyarakat di Desa Ketapang Raya Lombok Timur bertujuan: (1) solusi mengatasi masalah eksploitasi biota laut dan ekonomi nelayan skala kecil, (2) konservasi lingkungan berbasis komunitas nelayan kecil dan (3) kelompok nelayan kecil dapat berkontribusi secara berkelanjutan untuk stabilitas pangan yang bersumber dari laut. Selanjutnya, Manfaat program pengabdian pada masyarakat di wilayah Desa Ketapang Raya Lombok Timur adalah: (1) aspek ekonomi, nelayan skala kecil memiliki harapan baru untuk meningkatkan pendapatan selain sebagai nelayan, sumber matapencaharian yang berkelanjutan dan penciptaan lapangan kerja baru bagi keluarga nelayan dan masyarakat, (2) aspek lingkungan, pengembangan teknologi budidaya ramah lingkungan dapat mencegah over-eksploitasi biota laut yang menjadi sumber pakan budidya dan (3) aspek sosial, nilai kebersamaan dalam budidaya dapat menjadi modal sosial yang cukup penting untuk membangun kebersamaan masyarakat dalam membangun dan menjaga lingkungan dari pengaruh yang kurang positif.

\section{Metode Pelaksanaan}

\section{Tempat dan Waktu Pelaksanaan}

Program pengabdian pada masyarakat ini dilaksanakan di Desa Ketapang Raya Lombok Timur. Adapun waktu pelaksanaan dari kegiatan ini selama 4 bulan yaitu dari September 2016 Desember 2016.

\section{Sasaran Pelaksanaan}

Pengabdian pada masyarakat tentang penerapan teknologi budidaya ramah lingkungan memiliki sasaran utama yaitu kelompok nelayan skala kecil di Desa Ketapang Raya Lombok Timur. Selain kelompok nelayan sasaran kegiatan adalah nelayan skala kecil yang lain yang belum terlibat dalam usaha budidaya sebagai sumber matapencaharian selain sebagai nelayan.

\section{Pendekatan Pelaksanaan}

Indikator keberhasilan budidaya ramah lingkungan sebagai strategi pengentasan kemiskinan nelayan skala kecil di lokasi pengabdian ditentukan oleh strategi dan metode pendekatannya. Dalam hal 
ini pilihan pendekatan harus bersifat rasional sesuai dengan kondisi sosial ekonomi dan budaya nelayan skala kecil. Pendekatan ini tentu untuk mencapai tujuan berdasarkan ciri nelayan skala kecil (smallscale fisheries) yang memiliki kebiasaan kerjasama secara kelompok dalam satu unit kerja sebagai nelayan tangkap (Basurto et al., 2013 ). Pendekatan yang dimaksudkan dalam kegiatan pengabdian pada masyarakat ini adalah pendekatan kooperatif. Pendekatan kooperatif memiliki keunggulan sebagai sebuah pendekatan dalam pemberdayaan masyarakat karena memiliki sifat yaitu: (1) partisipatif, (2) koordinatif, (3) kolaboratif dan (4) konsultatif (Wright et al., 2006).

Tabel 1. Tahap pelaksanaan kegiatan

\begin{tabular}{|c|c|c|c|c|}
\hline No & Pokok Kegiatan & Materi & Metode & Nara Sumber \\
\hline \multirow[t]{2}{*}{1} & Orientasai & $\begin{array}{l}\text { 1. Makna teknologi budidaya ramah } \\
\text { lingkungan sebagai supelemen } \\
\text { matapencaharian nelayan skala kecil }\end{array}$ & $\begin{array}{l}\text { Diskusi informasi, } \\
\text { FGD dan Refleksi }\end{array}$ & TIM \\
\hline & & $\begin{array}{l}\text { 1. Rekonstruksi teknologi budidaya } \\
\text { ramah lingkungan yang bersumer } \\
\text { dari nelayan skala kecil }\end{array}$ & $\begin{array}{l}\text { Diskusi informasi, } \\
\text { FGD dan Refleksi }\end{array}$ & TIM \\
\hline 2 & $\begin{array}{l}\text { Pendampingan persiapan } \\
\text { pelaksanaan budidaya } \\
\text { ramah lingkungan }\end{array}$ & $\begin{array}{l}\text { 1. Penyiapan lokasi dan sarana } \\
\text { penempatan budidaya ikan } \\
\text { 2. Penderan bibit udang dan ikan }\end{array}$ & $\begin{array}{l}\text { Praktek, Diskusi } \\
\text { informasi, FGD } \\
\text { dan Refleksi }\end{array}$ & $\begin{array}{l}\text { Tim dan ketua } \\
\text { kelompok }\end{array}$ \\
\hline 3 & $\begin{array}{l}\text { Pendampingan pelaksanaan } \\
\text { budidaya ramah lingkungan }\end{array}$ & $\begin{array}{l}\text { 1. Pembesaran ikan pada lokasi yang } \\
\text { sudah disiapkan (keramba jaring } \\
\text { apung) } \\
\text { 2. Pemeliharaan dan keamanan }\end{array}$ & $\begin{array}{l}\text { Praktek, Diskusi } \\
\text { informasi, FGD } \\
\text { dan Refleksi }\end{array}$ & $\begin{array}{l}\text { Tim dan ketua } \\
\text { kelompok }\end{array}$ \\
\hline 4 & $\begin{array}{l}\text { Evaluasi pelaksanaan } \\
\text { budidaya ramah lingkungan }\end{array}$ & $\begin{array}{l}\text { 1. Kelayakan secara ekonomi sebagai } \\
\text { industri yang berbasis rumah tangga }\end{array}$ & $\begin{array}{l}\text { Diskusi informasi, } \\
\text { FGD dan Refleksi }\end{array}$ & Tim \\
\hline
\end{tabular}

\section{Hasil Dan Pembahasan}

\section{Budidaya Lobster}

Budidaya telah menjadi salah satu pilihan nelayan kecil sebagai sumber matapencaharian di wilayah pesisir Selatan Lombok. Budidaya lobster memiliki keunggulan dari budidaya yang lain karena merupakan komuditas ekspor. Namun demikian perkembangan cukup terbatas sampai tahun 2014 hanya berkembang di Teluk Jor. Pengembangan budidaya lobster oleh nelayan skala kecil, seperti di Desa Ketapang Raya dimulai dari inisiasi program penelitian MP3EI Universitas Mataram tahun 2015. Jenis budidaya lobster yang dikembangkan adalah lobster pasir (Panulirus homarus) dan mutiara (Panulirus ornatus). Kedua jenis lobster tersebut dapat tumbuh dengan baik pada lingkungan perairan pesisir di wilayah selatan Lombok Timur. Lama waktu budidaya lobster ditentukan oleh ukuran bibit

\section{Metode Pelaksanaan}

Program budidaya ramah lingkungan sesuai dengan pendekatan yang telah dirumuskan di atas dalam pelaksanaanya menggunakan metode pendididan dan pelatihan pembelajaran orang dewasa (andragogi). Tahapan dalam pelaksanaan (Tabel 1) di bawah ini.

\section{Pelaksanaan}

Pelaksanaan pengabdian ini secara rinci seperti pada (Tabel 1) di bawah ini. 
relevan yaitu lobster mudah dibudidaya dan harga lobster cukup tinggi.

Produksi lobster hasil budidaya rata-rata untuk satu kolam budidaya dengan jumlah antara 125 - 150 dan berat rara-rata 200 gram/ekor yaitu 25 $\mathrm{kg}-30 \mathrm{~kg}$. Hasil produksi dan nilai produksi lobster dapat memberikan gambaran tentang: (1) besarnya kontribusi budidaya lobster nelayan skala kecil dalam meningkatkan produksi udang lobster, (2) budidaya lobster dapat menjadi sumber matapencaraian baru nelayan skala kecil dan masyarakat lokal dan (3) budidaya lobster menjadi model baru untuk meningkatkan kesejahteraan nelayan kecil.

Nilai ekonomi budidaya lobster dapat memberikan dampak positif terhadap peningkatan pendapatan, sumber matapencaharian berkelanjutan dan sumber lapanagan kerja baru bagi nelayan skala kecil dan masyarakat lokal. Selain dampak ekonomi hal yang sangat penting dirasakan oleh para nelayan pembudidaya adalah kebersamaan antar pembudidaya yang dapat menjadi modal sosial yang sangat penting untuk kenyamanan dan ketentraman dalam kehidupan sehari-hari. Hal yang sangat penting bagi nelayan skala kecil adalah ada harapan baru bagi mereka, terutama sebagai sumber mata pencaharian pada kondisi rendahnya hasil tangkapan ikan.

\section{Teknologi Budidaya Ramah Lingkungan}

Budidaya lobster yang dikembangkan oleh nelayan skala kecil di perairan pesisir Lombok Timur adalah dengan menggunakan kramba jaring apung (KJA). Sistem budidaya dengan KJA sampai saat ini cukup berkembang dengan baik. Namun demikian pembudidaya memiliki masalah untuk mengembangkan budidaya karena terkendala dalam pengadaan pakan. Kondisi ini tentu membutuhkan inovasi untuk pengembangan budidaya agar terus dapat berkontribusi dalam meningkatkan kesejahteraan nelayan dan masyarakat lokal. Praktek yang banyak dilakukan oleh nelayan dala budidaya untuk pengadaan pakan adalah mencari beberapa jenis biota laut dari jenis echinodermata, moluska atau jenis lain yang menjadi sumber pakan untuk budidaya. Kondisi ini tentu sangat menghawatirkan karena telah terjadi over-eksploitsi dan tentu dapat berdampak negatif terhadap keberlanjutan biodiversity biota laut dan kerusakan lingkungan dan akhirnya berpengrauh terhadap penurunan kualitas lingkungan laut.
Budidaya laut yang telah berkembang membutuhkan inovasi agar tidak berdampak negatif terhadap lingkungan. Dalam hal ini tentu teknologi yang dibutuhkan adalah teknologi ramah lingkungan. Teknologi ramah lingkungan yang dapat dikembangkan adalah teknologi bagang apung sederhana sebagai alat untuk mencari pakan budidaya. Teknologi KJA yang dikembangkan adalah mengintegrasikan kramba jaring apung dengan bagang apung pada satu KJA. Sistem ini cukup efektif dan dapat memenuhi kebutuhan pakan budidaya. Melalui sisten integrasi KJA dengan bagang apung sederhana budidaya laut dapat berkembang dan mencegah dampak negatifnya terhadap keberadaan biota laut. Meskipun demikian masih dibutuhkan pengkajian teknologi dalam pengembangan pakan ramah lingkungan untuk keberlanjutan budidaya bagi nelayan skala kecil.

Pengembangan usaha budidaya laut harus menganut prinsip berkelanjutan, selain memberikan dampak positif terhadap terciptanya lapangan kerja, peningkatan pendapatan dan kesejahteraan juga diharapkan dapat mengurangi tekanan terhadap sumberdaya perikanan laut yang pemanfaatannya secara berlebih. Untuk itu, disarankan agar pengembangan bubidaya harus memperhatikan (a). Penggunaan teknologi yang ramah lingkungan, layak secara ekonomi dan dapat diterima oleh masyarakat, (b). Pengembangan budidaya disesuaikan dengan daya dukung lingkungan dengan menggunakan input yang tepat, tenaga terampil dan disertai monitoring lingkungan, (c). Kegiatan budidaya diharapkan dapat mensejahterakan kehidupan masyarakat. Oleh karena itu, upaya peningkatan kualitas lingkungan perairan sangat perlu dilakukan dengan menerapkan manajemen lingkungan yang komprehensif melalui pengembangan metode biomonitoring dan ekologi terapan guna meningkatkan kapasitas produksi dan sustainability operasionalnya.

Penerapan teknologi budidaya ramah lingkungan nelayan skala kecil dengan sasaran utama adalah kelompok nelayan skala kecil yang telah memiliki uasaha budidaya dan nelayan yang belum terlibat untuk budidaya. Hasil pelaksanaan pengabdian pada masyarakat berdasarkan strategi dan pendekatan yang telah dilakukan dapat dirumuskan adalah:

1. Penguatan kapasitas kelembagaan kelompok, pada tahap ini Tim pengabdian pada masyarakat memberikan orientasi tentang nilai dari teknologi 
budidaya ramah lingkungan untuk efisiensi dalam usaha budidaya. Hasil yang diperoleh melalui proses diskusi dan refleksi menunjukkan kelompok nelayan pembudidaya pada dasarnya telah memiliki pengetahuan tentang penerapan teknologi KJA dengan bagang apung sederhana dan telah ada contoh dari salah satu anggota kelompok pembudidaya. Dalam hal Tim pengabdian dan ketua kelompok lebih menekankan pada usaha yang dibutuhkan agar semua KJA memiliki bagang apung sederhana.

2. Penyiapan sarana teknologi budidaya ramah lingkungan, Tim melakukan pendampingan untuk mengoptimalkan potensi kelompok pembudidaya agar memiliki bagang apung sebagai sarana untuk memperoleh pakan. Hasil yang diperoleh melalui proses ini dari semua KJA dalam waktu satu bulan telah memiliki bagang apung sederhana sebagai alat untuk memperoleh pakan budidaya. Melalui pendampingan ini kelompok nelayan pembudidaya menunjukan sikap yang positif dan mudah bekerjasama baik antar mereka dalam kelompok maupun antar kelompok. Hal ini tentu menjadi modal yang cukup besar bagi kelompok pembudidaya untuk tumbuh dan berkembang menjadi pembudidaya yang berhasil secara ekonomi, sosial dan perbaikan kualitas lingkungan.

3. Penerapan teknologi budidaya ramah lingkungan, berdasarkan hasil observasi, diskusi dan refleksi dengan kelompok nelayan pembudidaya diperoleh hasil diantaranya adalah: (a) rata -rata tiap kramba jaring apung dengan sistem integrasi bagang apung memperoleh ikan berkisar antara 5- $10 \mathrm{~kg}$ tiap kali operasi dan sudah mencukupi untuk kebutuhan pakan budidaya, (b) sistem operasi bagang apung tidak dilakukan setiap hari tergantung pada peroleh untuk kebutuhan pakan budidaya, namun demikian rata-rata operasi bagang apung dilakukan tiap 3 hari sekali, (c) operasional bagang apung menggunakan energi yang bersumber dari tenaga surnya dengan sistem kerja pada siang hari dengan menggunakan acci 800 volt dan pada malam hari lampu dinyalakan.

4. Pelaksanaan budidaya lobster, hasil observasi, diskusi dan refleksi menunjukkan bahwa budidaya lobster dapat dikelompokkan menjadi dua tahap yaitu: (a) tahap pembesaran bibit lobster yang membutuhkan waktu 1-3 bulan dan (b) tahap pembesaran lobster yang membutuhkan waktu 3-5 bulan. Pada tahap pembesaran bibit adalah nelayan pembudidaya selalu dihantui oleh rasa kecemasan karena jumlah bibit yang dilepas pada kolam pembudidaya sering berkurang samapai $50 \%$ dari total bibit awal. Hal ini disebabkan karena kolam budidaya tidak memiliki pelindung yang menyebabkan banyak predator yang masuk kedalam kolam budidaya dan dari hasil analisis berdasarkan uji yang dilakukan dimana kolam budidaya ditutup sehingga tidak ada jalan predator masuk diperoleh pada bulan pertama kondisi udang jumlahnya tidak berbeda dengan jumlah awal. Oleh karena itu saat sekarang ini para pembudidaya sudah menemukan cara yang efektif untuk menangani masalah dalam usia budidaya dalam usia pembesaran bibit. Tahap pembesaran, pada tahap ini yang menjadi masalah nelayan pembudidaya adalah masalah pakan. Namaun demikian dengan teknologi bagang apaung yang dintegrasikan dengan kramba jaring apung masalah pakan sudah tidak lagi menjadi masalah dan nelayan pembudaya merasa sangat nyaman dan berharap sistem teknologi budidaya yang dikembangkan dapat memberikan kontribusi yang positif dari aspek ekonomi, lingkungan dan sosial.

5. Kelayakan secara ekonomi sebagai, hasil evaluasi Tim pengabdian pada masyarakat bahwa penerapan teknologi budidaya ramah lingkungan memiliki kontribusi secara ekonomi terutama dari pada proses produksi. Hal ini dapat dijelaskan berdasarkan beberapa intrumen produksi diantaranya adalah: (a) pengadaan pakan budidaya, dimana nelayan tidak mengeluarkan finansial untuk membeli kebutuhan pakan tetapi sudah cukup dari hasil tangkapan bagang apaung, (b) waktu mencari pakan tidak mengganggu waktu mereka untuk kebutuhan lain, karena smabil menjaga udang mereka dapat mengoperasikan bagang apung untuk memperoleh pakan dan (c) bibit lobster dapat diperoleh pada saat mengoperasikan bagang apung, sehingga nelayan pembudidaya memiliki stok bibit untuk keberlanjutan budidaya dan tidak mengeluarkan biaya untuk membeli bibit udang untuk budidaya.

Teknologi budidaya ramah lingkungan memiliki nilai ekonomi, lingkungan dan sosial bagi nelayan dan masyarakat di Desa Ketapang Raya. Berdasarkan hasil analisis selama proses pelaksanaan pengabdian pada masyarakat telah 
teriidentifikasi beberapa kondisi objektif sebagai faktor positif dalam untuk penerapan teknologi budidaya ramah lingkungan di lokasi pengabdian pada masyarakat adalah sebagai berikut:

1. Kesiapan kelompok nelayan pembudidaya, nelayan pembudidaya di lokasi pengabdian pada masyarakat telah mamahami nilai positif budidaya untuk meningkatkan pendapatan. Nilai positif budidaya dari aspek ekonomi sebagai salah satu kunci atau faktor pendorong utama untuk penerapan teknogi budidaya ramah lingkungan di wilayah perairan pesisir Desa Ketapang Raya Lombok Timur. Selain itu kesiapan kelompok budidaya dapat dilihat dari partisipasinya dalam mengembangkan keramba jaring apung dengan sistem yang terintegrasi dengan bagang apung.

2. Teknologi budidaya ramah lingkungan bersifat sederhana dan dapat dioperasikan dengan mudah oleh nelayan pembudidaya. Teknologi sederhana yang ada pada sisitem KJA yang mengintegrasikan bagang apung pada satu kesatuan menjadi faktor penting mudahnya nelayan pembudidaya untuk memodifikasi KJA yang telah dimiliki.

3. Pakan, kesulitan pakan dalam budidaya telah menyebabkan para nelayan pembudidaya memilih teknologi budidaya ramah lingkungan untuk melanjutkan budidaya sebagai sumber matapencaharaian yang berkelanjutan.

4. Aspek ekonomi, dalam hal ini nelayan pembudidaya telah memahami besarnya nilai ekonomi yang diperoleh dari usaha budidaya lobster, sehingga mendorong mereka untuk mengembangkan budidaya sebagai sumber matapencaharian yang berkelanjutan dan lapangan kerja baru bagi keluerga nelayan dan masyarakat.

5. Asepk sosial, nilai kebersamaan dalam budidaya menjadi modal yang sangat penting untuk kebersamaan dalam menyelesaikan masalahmasalah sosial yang lain, sehingga faktor ini telah menjadi motivasi mereka untuk melibatkan nelayan lain untuk melakukan budidaya.

6. Nelayan pembudidaya memiliki pengetahuan dan ketrampilan yang memadai untuk mengoperasikan sistem teknologi budidaya ramah lingkungan dan telah menyebabkan pembudidaya di lokasi pengabdian pada masyarakat memanfaatkan secara optimal sarana yang dimiliki.
7. Potensi produk budidaya lobster, produk budidaya lobster merupakan komuditas ekspor dan nilai tiap satu kg cukup tinggi yaitu berkisar antara Rp. 250.000,- Rp. 350.000,- untuk lobster pasir dan Rp. 400.000,- - Rp. 550.000,- untuk lobster mutiara.

8. Dukungan pihak lain, dalam hal ini pemerintah desa memberikan motivasi pada kelompok budidaya untuk meningkatkan kapasitas agar dapat menjadi matapencaharian baru bagi masyarakat saat ini dan yang akan datang.

Penerapan teknologi budidaya ramah lingkungan cukup efektif sebagai solusi ekonomi nelayan skala kecil di Desa Ketapang Raya. Namun demikian masih ada beberapa kendala untuk pengembangannya. Salah satu kendala khususnya bagai pembudidaya baru adalah adanya tambahan biaya untuk fasilitas bagang apaung pada KJA. Selain faktor ekonomi masalah lain yang menjadi kendala adalah kelembagaan kelompok nelayan pembudidaya yang belum dapat melakukan kerjasama dengan pihak lain untuk mengembangkan budidaya pada skala yang lebih besar.

\section{Kesimpulan}

Teknologi adalah hal yang dibutuhkan untuk membantu nelayan skala kecil baik di lokasi pengabdian pada masyarakat maupun desa lain. Oleh karena itu kedepan diperlukan inovasi pada aspek lain agar nelayan skala kecil terus dapat berkontribusi dalam stabilitas ketahanan pagan yang bersumber dari laut. Dalam hal ini Tim pengabdian pada masyarakat dari Universiatas Mataram pada tahun berikutnya agar dapat memberikan inovasi baru dalam aspek ekonomi pasca produksi agar kelompok pembudidaya memiliki akses yang lebih luas untuk mengembangkan budidaya ramah lingkungan untuk komuditas yang lain. Penerapan teknologi budidaya ramah lingkungan memiliki makna yang cukup startegis sebagai solusi mengatasi masalah sulitnya alternatif dalam meningkatkan pendapatan dan kerusakan lingkungan akibat over-exploitasi untuk memperoleh pakan budidaya. Oleh karena itu dari proses yang telah dilakukan dalam pengabdian pada masyarakat dapat dirumuskan kesimpulannya adalah:

1. Teknologi budidaya ramah lingkungan yang mengintegrasikan KJA dengan bagang apung 
pada satu sistem cukup efektif untuk keberlanjutan usaha budidaya lobster nelayan skala kecil di Desa Ketapang Raya.

2. Budidaya lobster telah memberikan harapan baru bagi nelayan skala kecil untuk mendapatkan matapencaharaian yang berkelanjutan dan meningkatkan pendapatan serta tumbuhnya lapangan kerja baru.

3. Budidaya dengan teknologi ramah lingkungan telah mampu mengatasi masalah pakan budidaya dan berdampak posistif terhadap keberadaan biota laut yang sebelumnya diekploitasi sebagai sumber pakan budidaya.

4. Kelompok pembudidaya memiliki respon yang sangat positif terhadap pengembangan teknologi budidaya ramah lingkungan.

\section{Ucapan Terima Kasih}

Tim pengabdian pada masyarakat menyampaikan ucapan terima kasih kepada Bapak Rektor Universitas Mataram yang telah memberikan bantuan dana untuk pelaksanaan kegiatan pengabdian pada masyarakat ini melalui sumber dana BOPTN Universitas Mataram 2016.

\section{Daftar Pustaka}

Basurto, X., A. Bennett, A. Hudson Weaver, S. Rodriguez-Van Dyck, and J.-S. AcevesBueno. 2013. Cooperative and noncooperative strategies for small-scale fisheries' self-governance in the globalization era: implications for conservation. Ecology and Society 18 (4): 38.

Badan Pusat Statistik Lombok Timur. 2014. Lombok Timur dalam Angka. Selong Lombok Timur NTB Dinas Perikanan dan Kelautan Kabupaten Lombok Timur. 2014. Statistik Perikanan. Selong Lombok Timur.

Karnan, M.S. Baskoro, B.H. Iskandar, E. Lubis, dan Mustaruddin, 2012, Perikanan cumi-cumi di Perairan Selat Alas Nusa Tenggara Barat. Jurnal Biologi Tropis, 13(1): 8-14.
Perez, M.L, M.D. Pido, L.R. Garces dan N.D. Salayo. 2012. Towards Sustainable Development of Small-Scale Fisheries in the Philippines: Experiences and Lessons Learned from Eight Regional Sites. WorldFish. Penang, Malaysia.

Profil Desa Kepatang Raya. 2014. Desa Ketapang Raya Kecamatan Keruak Kabupaten Lombok Timur.

Syukur, A. 2013. Pengetahuan Ekologi Masyarakat Lokal sebagai Indikator Penilaian Potensi Lamun (Seagrass) di Tanjung Luar Lombok Timur. Jurnal Biologi Tropis, 13 (2): 209-217

Syukur, A. 2015. Distribusi, Keragaman Jenis Lamun (Seagrass) dan Status Konservasinya di Pulau Lombok. Jurnal Biologi Tropis, 15 (2):171-182

Syukur A, Mahrus, Syachruddin. 2016. The potential assessment environment friendly aquaculture of small-scale fishermen as a conservation strategy seagrass beds in coastal areas of Tanjung Luar East Lombok, Indonesia. International Journal of Fisheries and Aquatic Studies, 4 (2): 22-27.

Syukur, A., Wardiatno, Y., Muchsin, I., and Kamal, M.M . 2017. Threats to Seagrass Ecology and Indicators of the Importance of Seagrass Ecological Services in the Coastal Waters of East Lombok, Indonesia. American Journal of Environmental Sciences, 13 (3): 251.265

Wright, A., Stacey, N. dan Holland, P. 2006. The cooperative framework for ocean and coastal management in the Pacific Islands: Effectiveness, constraints and future direction. Ocean and Coastal Management: 49, $739-763$. 